\title{
COMPARISON OF THIOPENTONE AND MIDAZOLAM FOR INDUCTION OF ANAESTHESIA: INFLUENCE OF DIAZEPAM PREMEDICATION
}

\author{
Brendan T. Finucane, Julian Judelman and Rebecca Braswell
}

\begin{abstract}
Forty-eight healthy patients undergoing routine surgery participated in this double-blind parallel study in which thiopentone sodium and midazolam maleate were compared for induction of anaesthesia. Twelve patients in each group received diazepam premedication. The purpose of this study was three fold; first to compare the efficacy of these two drugs as induction agents using fixed criteria, second to find the optimal dose of midazolam for induction and, finally, to evaluate the effects of diazepam premedication on the induction dose of both drugs.

The results showed that adequate induction of anaesthesia was achieved using 0.30 milligrams per kilogram of midazolam and 3.99 milligrams per kilogram of thiopentone. These doses were not altered by pre-operative medication with diazepam. The recovery time was significantly prolonged in those patients who had received midazolam. The shortest recovery time was observed in those patients who had received thiopentone with diazepam. There were four cases of phlebitis in the thiopentone group and two in the midazolam group.

In conclusion, midazolam maleate, which is a water soluble benzodiazepine, provided satisfactory induction of anaesthesia at a dose of 0.30 milligrams per kilogram. However recovery time was significantly prolonged in patients who received midazolam.
\end{abstract}

Key Words: Anaesthetics, intravenous, thiopentone, midazolam: PremedicaTION, diazepam.

THIOPENTONE HAS ENJOYED incomparable success as an intravenous anaesthetic agent since the 1930 's. ${ }^{1}$ Its main strength lies in the fact that induction and recovery are extremely rapid. This agent is considered the prototype to which all new intravenous anaesthetic agents are compared.

In the early 1960's the benzodiazepine diazepam was introduced in Europe and, since then, it has been studied extensively. The first reports of its use as a sole intravenous anaesthetic agent appeared in $1964^{2}$ and $1965 .{ }^{3}$ It was soon noted that diazepam had certain serious limitations in this role. It causes pain in injection due to venous irritation and induction of anaesthesia is prolonged, taking at least three minutes in most cases. There is a tremendous variability in individual dose requirements. The plasma half-

Brendan T. Finucane, M.D., F.R.C.P.(C), FFARCS., Julian Judelman, M.D., FFARCS., Rebecca Braswell, R.N., Department of Anaesthesia, Grady Memorial Hospital, Emory University School of Medicine, 80 Butler Street, S.E., Atlanta, Georgia 30336 U.S.A.

This study was supported by a grant from HoffmanLa Roche Inc.

Can. Anaesth. Soc. J., vol. 29, no. 3, May 1982 life of diazepam is in excess of 20 hours and is even more protracted in extremes of age. ${ }^{4}$ Its use as a sole induction agent is now reserved for those circumstances where it is particularly important to avoid cardiovascular depression. ${ }^{5}$

Further pharmacological investigation of the benzodiazepines led to the development of midazolam (R021-3981). Studies to date indicate that midazolam has many of the desirable properties of diazepam without the undesirable side effects. It is water soluble and therefore theoretically should not cause pain or irritation on injection. Its half-life is approximately two hours. ${ }^{6}$ It also has a greater margin of safety in animals. Using this background, a study was designed to test the proficiency of midazolam as an intravenous anaesthetic agent by comparing it with thiopentone.

\section{Materials and Methods}

The primary purpose of this study was to find the dose of midazolam that would satisfactorily induce anaesthesia. Secondary objectives were to compare midazolam with thiopentone in terms 
TABLE I

Patient Characteristics

\begin{tabular}{lllll}
\hline \multicolumn{1}{c}{ Group } & Age (Yrs.) & Weight (kg) & o & q \\
\hline Thiopentone & $30 \quad \pm 2.70$ & $75.58 \pm 5.59^{*}$ & 4 & 8 \\
Thiopentone D & $28.80 \pm 3.00$ & $62.04 \pm 3.21$ & 3 & 9 \\
Midazolam & $30.1 \pm 2.99$ & $65.30 \pm 3.75$ & 5 & 7 \\
Midazolam D & $32.9 \pm 3.26$ & $68.30 \pm 4.22$ & 5 & 7 \\
\hline
\end{tabular}

$\mathrm{D}=$ diazepam premedication.

Data represent mean \pm S.E. for 12 patients in each group.

$* \mathrm{P}<0.001$.

of onset of action and time to recovery. The final objective was to determine the influence of diazepam premedication on these parameters.

The protocol was reviewed by the Human Investigation Committee at Emory University. Informed consent was received from all 48 participants in the study. All patients were healthy. They were divided into four groups of 12 each. Group I received thiopentone alone, Group II received thiopentone and diazepam premedication, Group III received midazolam alone and Group IV received midazolam with diazepam.

The patient characteristics were comparable in each group, with the exception that patients in group I were significantly heavier than those in the other three groups. In addition, the number of females participating in all groups exceeded the number of males (Table I). The premedication consisted of diazepam $10 \mathrm{mg}$ and was administered orally between 30 and 75 minutes before operation. The study drug was injected intravenously through an injection port placed at a uniform distance from the intravenous catheter in each patient. The study drug was selected randomly by the principle investigator. Neither the anaesthetist nor the nurse observer were aware of which drug was being injected.

The criteria for induction were loss af eyelid reflex, loss of response to commands and loss of voluntary movement. The initial dose of thiopentone selected was $3 \mathrm{mg} \cdot \mathrm{kg}^{-1}$ and of midazolam $0.15 \mathrm{mg} \cdot \mathrm{kg}^{-1}$. If the criteria for induction were not satisfied within two minutes of the original injection, a further 25 per cent increment of the original dose was given over a five second period. Further increments were given every two minutes until the induction criteria were satisfied. If induction was not achieved after four increments, the patient was induced by other conventional means. The initial induction dose of each drug was increased when two out of three patients in each group required increments to satisfy the criteria for induction.

Anaesthesia was maintained using nitrous oxide, oxygen and halothane or ethrane. The criteria for recovery included satisfactory re-

TABLE II

TOTAL INDUCTION DOSE

\begin{tabular}{lc}
\hline \hline \multicolumn{1}{c}{ Group } & $\mathrm{mg} \cdot \mathrm{kg}^{-1}$ \\
\hline Thiopentone & $4.11 \pm 0.24$ \\
Thiopentone D & $3.88 \pm 0.27$ \\
Midazolam & $0.32 \pm 0.02$ \\
Midazolam D & $0.28 \pm 0.02$ \\
\hline \multicolumn{2}{c}{ D = diazepam premedication. } \\
Data represent mean \pm S.E. for 12 \\
patients in each group.
\end{tabular}

TABLE III

Time FROM INJECTION TO INDUCTION

\begin{tabular}{lc}
\hline \hline \multicolumn{1}{c}{ Group } & Minutes \\
\hline Thiopentone & $3.05 \pm 0.90$ \\
Thiopentone D & $3.00 \pm 0.79$ \\
Midazolam & $4.89 \pm 1.25$ \\
Midazolam D & $4.39 \pm 0.90$ \\
\hline \multicolumn{2}{c}{$\mathrm{D}=$ diazepam premedication. } \\
Data represent mean \pm S.E. for 12 \\
patients in each group.
\end{tabular}

TABLE IV

Time From InJection to Induction for COMBINED GROUPS

\begin{tabular}{lc}
\hline \hline Group & Minutes \\
\hline $\begin{array}{l}\text { Thiopentone } \\
+ \text { Thiopentone D }\end{array}$ & $3.03 \pm 0.59$ \\
$\begin{array}{l}\text { Midazolam } \\
\text { + Midazolam D }\end{array}$ & $4.64 \pm 0.78^{*}$ \\
\hline
\end{tabular}

$\mathrm{D}=$ diazepam premedication.

Data represent mean \pm S.E. for 24 patients in each group.

$* \mathrm{P}<0.05$ 
FINUCANE, et al.: COMPARISON OF THIOPENTONE AND MIDAZOLAM

TABLE V

Time From Entry to Recovery Room to Response (Minutes)

\begin{tabular}{|c|c|c|c|}
\hline Group & Q1 & Q2 & Q3 \\
\hline $\begin{array}{l}\text { Thiopentone } \\
\quad+\text { Thiopentone D } \\
\text { Midazolam }\end{array}$ & $5.29 \pm 1.23^{*}$ & $9.00 \pm 1.84^{*}$ & $8.66 \pm 1.84^{*}$ \\
\hline + Midazolam D & $10.16 \pm 2.85$ & $17.83 \pm 3.77$ & $15.16 \pm 3.05$ \\
\hline
\end{tabular}

sponses to three questions relating to, response to commands, orientation to place and cognitive ability $\left(Q_{1}, Q_{2}, Q_{3}\right.$, Table V). An SMA 18 chemical profile was obtained from each patient before and after the procedure.

The results showed that preoperative medication of patients with diazepam did not significantly alter induction doses of either thiopentone or midazolam (Table II); nor did it significantly alter the time from injection to induction (Table III). However, the time from injection to induction was more protracted in the combined midazolam group (Table IV). Finally, it was demonstrated that recovery times were significantly prolonged in patients who had received midazolam (Table V).

\section{Discussion}

One of the main purposes of this study was to find a dose of midazolam that would satisfactorily induce anesthesia in mildly premedicated or unpremedicated patients. It was rapidly learned that diazepam $10 \mathrm{mg}$ given preoperatively had no significant effects on the induction dose, onset of action, or time of recovery of these patients. The induction time was significantly shorter in patients who received thiopentone. The mean induction dose of midazolam required before the criteria of induction were satisfied was $0.3 \mathrm{mg}$ per kilogram. This is approximately double the dose suggested by previous investigators. ${ }^{7}$ Miller, et $a{ }^{8}{ }^{8}$ following a protocol similar to this one, also found it necessary to infuse $0.3 \mathrm{mg} \cdot \mathrm{kg}^{-1}$ of midazolam before induction was satisfactory. The major reason for this disparity in dose requirement lies in the speed at which the drug was administered. In this study midazolam was administered over a 30 second period. Those investigators reporting lower dose requirements injected the drug in 15 seconds. Furthermore, the criteria for induction were far less stringent in those latter groups. Dundee $^{9}$ has suggested that this large variation in dose requirements may be explained on the basis that midazolam is highly protein bound ( 95 per cent). The correct dosage using the usual criteria of induction probably lies somewhere between these two doses. Reves, et al. reported satisfactory induction in all patients who had received $0.2 \mathrm{mg} \cdot \mathrm{kg}^{-1}$ given over a 15 second period. ${ }^{10}$

Although it seems quite clear that midazolam lacks many of the advantages of thiopentone as an intravenous induction agent, it does have some major advantages. Like diazepam it causes minimal depression of the cardiovascular system in patients with normal cardiovascular function and, based on other studies, does not appear to cause venous thrombosis. Following intravenous injection midazolam is rapidly metabolized to 1-hydroxymethyl and 4-hydroxy metabolites, ${ }^{11}$ neither of which exert any significant depressant effect on the central nervous system. These metabolites appear in the plasma between five and $\mathbf{2 0}$ minutes following intravenous injection in animals. Diazepam behaves similarly initially, but plasma levels reach a second peak six to eight hours after injection. One of the metabolites of diazepam, desmethyldiazepam, ${ }^{12}$ is pharmacologically active and plasma levels gradually increase over a 48 hour period. This explains the more evanescent action of midazolam.

In conclusion it seems that midazolam may be a useful intravenous anaesthetic agent in patients with cardiovascular instability secondary to primary cardiac disease or volume depletion.

\section{REFERENCES}

1. Pratt, T.W., Tatum, A.L., Hathaway, H.R. \& WATERS, R.M. Sodium ethyl thiobarbiturate: Preliminary experimental and clinical study. Amer. Jour. Surg., 31: 464 (1936). 
2. Campan, L. \& Espagno, M-TH. Note Sur le Diazepam en Anesthesiologie. Annales de l'anesthesiologie francaise 5; 711-720 (1964).

3. Blondeau, P. Diazepam et Anesthesia Generale, Cahiers d'Anesthesiologie, 13: 207-217 (1965).

4. Kaplan, S.A., Jack, M.L., Alexander, K. \& WeINFELD, R.E. Pharmacokinetic profile of diazepam in man following single intravenous and oral and chronic oral administrations. J. Pharm. Sci. 62: 1789-1796 (1973).

5. Dalen, J.E., Evans, G.L., Banas, J.S., et $a l$. The hemodynamic and respiratory effects of diazepam. Anesthesiology 30: 259-263 (1969).

6. Brown, C.R. SARnouist F.H., Canup, C.A \& PEDLEY, T.A. Clinical, electroencephalogtaphic and pharmacokinetic studies of a watersoluble benzodiazepine, midazolam maleate. Anesthesiology 50: 467-470 (1969).
7. Frazer, R.J., Zahl, F. \& Caldwell, N. A water-soluble benzodiazcpine, RO 21-3981, for induction of anesthesia. Anesthesiology 49: 4163 (1978.

8. Miller, R., Eisendraft, J.B., Jaffee, D.H., et al. Comparison of midazolam with thiopental for anesthesia induction. Effect of innovar premedication. Anesthesiology Review 7: 21-27 (Dec. 1980)

9-11. DundeE, J.W. New IV Anaesthetics, Br. J. Anaesth. 51: 641-648 (1979).

10. Reves, J.G., Corssen, G. \& Holcomb, C. Comparison of two benzodiazepines for anesthesia induction: Midazolam and Diazepam, Can. Anaes. Soc. J. 25: 211-214 (1978)

12. DunDEE, J.W. \& WYANT, G.M. Intravenous Anaesthesia, Churchill, Livingston, Edinburgh, \& London, 1974, 1st Edition, p. 251

\section{RESUMÉ}

Quarante-huit patients en bon état subissant une intervention en chirurgie réglée ont particjpe à cette étude à étude à double insu au cours de laquelle le thiopentone sodique et le maléate de midazolam ont été comparés pour l'induction de l'anesthésie. Douze patients de chaque groupe avaient rę̧u du diazepam en prémédication. Cette étude avait trois objectifs; d'abord, de comparer l'efficacité de ces deux médicaments comme agents d'induction en utitisant des critères fixes, deuxièmement de trouver la dose optimale de midazolam pour l'induction et finalement d'évaluer les effets de la prémédication au diazepam sur la dose d'induction des deux médicaments.

Les résultats ont montré qu'une induction adéquate de l'anesthésie était réalisable avec midazolam $0.30 \mathrm{mg} \cdot \mathrm{kg}^{-1}$ et thiopentone $3.99 \mathrm{mg} \cdot \mathrm{kg}^{-1}$. Le réveil s'est prolongé de façon significative pour le groupe de patients chez qui on a utilisé le midazolam. La période de réveil la plus courte est survenue chez les patients qui avaient reçu du thiopentone précédé de diazepam. On a compté quatre cas de phlébite dans le groupe thiopentone et deux dans le groupe midazolam.

En conclusion, le maléate de midazolam qui est une benzodiazépine hydrosoluble a ptoduit une induction satisfaisante à la dose de $0.30 \mathrm{mg}^{-1} \mathrm{~kg}^{-1}$. Cependant, la période de réveil a été prolongée de façon significative chez ceux qui avaient reçu du midazolam. 